REPORT

Free Speech, Student Activism, and Social Media

Reflections from the Bowen Colloquium on Higher Education Leadership

February 28, 2018

Catharine Bond Hill

Kevin M. Guthrie

Martin Kurzweil

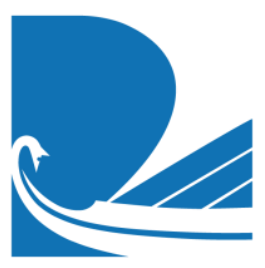

ITHAKA S+R 


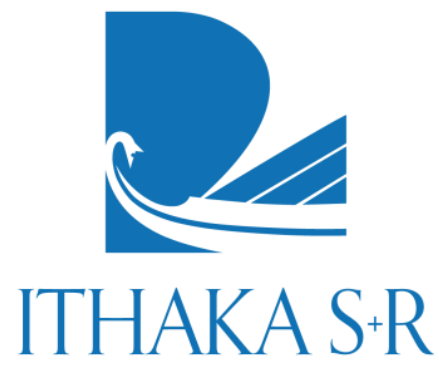

Ithaka $\mathrm{S}+\mathrm{R}$ provides research and strategic guidance to help the academic and cultural communities serve the public good and navigate economic, demographic, and technological change. Ithaka $\mathrm{S}+\mathrm{R}$ is part of ITHAKA, a not-for-profit organization that works to advance and preserve knowledge and to improve teaching and learning through the use of digital technologies. Artstor, JSTOR, and Portico are also part of ITHAKA.
Copyright 2018 ITHAKA. This work is licensed under a Creative Commons Attribution-NonCommercial 4.0 International License. To view a copy of the license, please see http://creativecommons.org/licenses/by-nc/4.0/.

ITHAKA is interested in disseminating this brief as widely as possible. Please contact us with any questions about using the report: research@ithaka.org.

We thank the following organizations for their support of The William G. Bowen Colloquium:

- Alfred P. Sloan Foundation

- The Andrew W. Mellon Foundation

- Denison University

- Princeton University

- TIAA 
On November 7, 2017, Ithaka S+R hosted the first Bowen Colloquium on Higher Education Leadership. Named for our late, founding board chair, William G. Bowen, the president emeritus of Princeton University and The Andrew W. Mellon Foundation, the event brought together 50 higher education leaders and experts to discuss current issues facing colleges and universities. The discussions were wide ranging and off the record. This paper presents our reflections-deeply informed by the discussion at the Colloquium-on one of the major themes discussed: free speech, student activism, and social media on campus. For more information on the Bowen Colloquium program and participants, including papers on the other topics discussed, visit http://www.sr.ithaka.org/landing/the-william-g-bowen-colloquium.

"We don't invite people here [to speak] because we agree with them. The right question, well phrased, can be far more effective than preventing people from speaking."

-William G. Bowen, quoted in Priscilla Van Tassel, "Bowen Reviews His Years at Princeton," The New York Times, November $29,1987.1$

\section{Summary of the issue}

Over the last few years, a large number of institutions have faced student unrest around a variety of issues, including racism, sexual assault, police violence, and divestment that have been challenging, disruptive, and sometimes even violent. ${ }^{2}$ Much of the unrest has been about broad societal issues, as well as specific campus policies related to these national issues, as students have grown disillusioned by national policies and political developments. Social media has both amplified and complicated the response to this unrest compared to past periods of student activism. As our country continues to confront these issues, and given demographic changes in the U.S. and the likely continuation of the gap between the "haves" and the "have nots," we are likely to see continued protests and tensions. It is possible that the recently passed tax legislation will further worsen income inequality, reinforcing the trends of the last few decades, which in turn will worsen current student discontent.

\footnotetext{
${ }^{1}$ Available at http://www.nytimes.com/1987/11/29/nyregion/bowen-reviews-his-years-at-princeton.html.

2 The authors thank the following Ithaka S+R staff members for their contributions to this paper: Rayane Alamuddin, Melissa Bender, Jenna Joo, Kimberly Lutz, Elizabeth Davidson Pisacreta, Daniel Rossman, and Emily Schwartz.
} 


\section{ITHAKA S+R}

Not only are students protesting national issues in the campus environment, they are also targeting college and university administrations. Presidents, in particular, are increasingly the targets of student unrest, with protesters asking for, or more often demanding, change on issues ranging from divestment of certain investments to Title IX policies to the names used on statues or colleges. One reason for these protests is that students consider their college and university campuses to be idealistic communities, and then realize that these institutions are not able to completely live up to their expectations. Colleges and universities are not immune to the issues facing our society more broadly.

In the view of college and university leaders, many student protesters demonstrate an unwillingness to discuss the issues, much less debate them, and instead come with their minds made up. Rather than engaging with and debating issues face-to-face or in the campus setting, they state their views on social media. This form of communication can significantly increase exposure of the event or issue beyond the campus, reaching alumni and even involving the national media in some cases. The perception is that students take advantage of institutions' commitment to free speech to exercise their own rights, but at the same time see no irony in preventing others from exercising those same rights. From some students' perspective, on the other hand, protecting free speech and a commitment to civil discourse are seen as tools or privileges of those with power, and are therefore suspect.

Invited campus speakers have been a common focal point of this unrest. There are numerous examples of speakers, from both ends of the political spectrum, who have been prevented from speaking on college campuses. Often students object to the content of the speech, but sometimes they object to an affiliation or past activity of the speaker, or that there is not enough diversity among those given speaking platforms. Protests connected to controversial speakers, picked up by the media, have led to national discussions about whether free speech is adequately protected on college campuses, as well as accusations of political bias on campus, with conservatives arguing that their views are not welcome. These national debates are occurring in the context of reduced public support for higher education among some segments of the population. ${ }^{3}$

Another manifestation of this issue that has alienated some observers is students asking for "safe spaces" where certain ideas (or people with those ideas) are excluded, raising concerns about academic institutions' commitment to open inquiry. In a similar vein, students want institutions to recognize "microaggressions" as unacceptable behavior and for institutions to find a way to address them when they occur. While these requests may

3 "Sharp Partisan Divisions in Views of National Institutions," Pew Research Center, July 10, 2017. 


\section{ITHAKA S+R}

be perceived by some as reflecting an expectation of special protection, it is important to keep in mind that members of majority groups may feel inherently more comfortable on campuses that have long histories of primarily serving majority students. Recognizing this casts the issue in a different light: groups that have not traditionally been a part of the campus community are asking for similar comfortable spaces.

\section{While probably never considered completely apolitical, today the pursuit of knowledge has itself become highly politicized.}

The current political climate also raises a broader, epistemic challenge for higher education. The university has historically been seen as a place dedicated to the pursuit of knowledge. While probably never considered completely apolitical, today the pursuit of knowledge has itself become highly politicized. ${ }^{4}$ Even faculty in the natural sciences, who historically have been less politically active, have been pulled into the debates, as their research-and indeed, the value of their methodology-is being questioned.

Finally, media coverage of student protests generally focuses on selective, betterresourced institutions. Students at open access institutions face the same national issues as students on selective college campuses, and indeed, as they are more likely to come from lower-income and non-white backgrounds, may be more directly affected by issues of income inequality and institutional racism. At the same time, practical concerns related to family, work, and school, and generally having more at stake in maintaining their position at their college, may inhibit those students' ability to engage in activism.

\footnotetext{
${ }^{4}$ Hannah Fingerhut, "Republicans Skeptical of Colleges' Impact on U.S., but Most See Benefits for Workforce Preparation," Pew Research Center, last updated July 20, 2017, http://www.pewresearch.org/fact-tank/2017/07/20/republicans-skeptical-of-collegesimpact-on-u-s-but-most-see-benefits-for-workforce-preparation/.
} 


\section{Why is this issue important?}

These events have impacted college campuses in a variety of ways, some with positive results, others with negative ones.

\section{In many cases, students have protested policies, and administrators have responded with beneficial changes that have improved campus life.}

In many cases, students have protested policies, and administrators have responded with beneficial changes that have improved campus life. Examples include greater recognition of implicit bias, increased attention to student housing and food insecurity and the need for emergency aid, and the growing concerns about and focus on the prevalence of sexual harassment and assault. Similarly, changes in the way colleges respond to concerns about sexual assault, while not completely uncontroversial, have led to heightened recognition of the problem and in many cases led to improved policies and procedures. While the ways in which some students have presented their views, often as demands, raise some issues about the types of interactions we would ideally have on our academic campuses, they have created needed impetus to address important problems.

On the other hand, one unfortunate consequence of a heated, polarized environment is that it is those at the extremes who end up most engaged, leaving out the broad group who hold more moderate views. Dialing down the intensity and hostility of debate around controversial topics is likely to lead to broader engagement. In some cases, the challenge of controversial speakers has led to violence. This of course is a detriment to the campus environment and student safety in its own right, but also results in significant financial costs to institutions that must ensure the safety of its campus community. 5 The very high costs associated with securing this kind of speech raises an important question: if it costs a public institution that is facing budget shortages hundreds of thousands of dollars to provide security for speakers to come to campus, can that institution limit access to speakers because the costs cannot be borne without disrupting the budget needed for core mission activities? It can be argued that our democracy is indebted to those institutions that have incurred substantial costs to

5 Suhauna Hussain, "The Costs of the Campus Speech Wars Are Piling Up for the Police," The Chronicle of Higher Education, July 3, 2017, https://www.chronicle.com/article/The-Costs-of-the-Campus-Speech/240527. 
protect controversial speech, but how much is too much for a single institution to bear? Perhaps resources could be pooled to protect this important right, or other mechanisms could be created to help cover these costs.

There are also public relations challenges that must be managed. The recent increase in student unrest, combined with the ubiquitous presence of social media, can make what used to be a local issue that could be addressed deliberately and thoughtfully in a small community into a national or international incident stoked by the 24 hour news cycle. The media, and in particular social media, have amplified student protests and local events, fanning flames and sometimes distorting public perception of what is happening on college campuses. Effectively communicating countervailing narratives of more normal behavior on campuses-including the common occurrence of hosting speakers from across the ideological spectrum without incident-is exceedingly difficult.

\section{The media, and in particular social media, have amplified student protests and local events, fanning flames and sometimes distorting public perception of what is happening on college campuses.}

Protests and the resulting publicity have affected the public's views of higher education, mostly in negative ways. Students are perceived as entitled, "snowflakes," rude, and wasting resources. Since institutions, both private and public, rely on public support, these negative perceptions put that support at risk. To some extent, provisions in the recent tax legislation targeting higher education can be linked to these negative public perceptions; at the very least, these policy changes are a real and costly demonstration of the pervasiveness of this reputation.

As a matter of mission and principle, higher education institutions have long been committed to encouraging free speech and supporting lively debate of issues.

Withdrawing invitations to certain speakers and cancelling speeches by others has raised concerns about higher education's current commitment to free speech. Increasingly, students do not believe in the principle of freedom of speech, if they disagree with the 
point of view. ${ }^{6}$ Since freedom of speech is a core principle of our society and democracy, the fact that students are questioning its value, and behaving in ways that violate these principles, is worrying.

\section{If some - the government, university administrators, or students for that matter-get to decide what speech is acceptable and what questions can be asked, we risk our commitment to the pursuit of new knowledge.}

The United States' protection of free speech is robust. Speech that attacks groups of individuals, even when considered highly objectionable by the majority of listeners, is protected speech. While the law imposes different constraints on public and private institutions of higher education, all have the obligation of educating the next generation and this includes educating them on the issues and controversies surrounding the first amendment. Encouraging discussion of difficult issues from multiple perspectives will likely be a part of that obligation at any institution, along with the associated security and other costs. In the end, students will need to decide for themselves the value of our nation's interpretation of the First Amendment to date, and decide if it is a valuable principle going forward. Because of its relationship to academic freedom and advancing knowledge, the position universities ought to take seems clear. If some-the government, university administrators, or students for that matter-get to decide what speech is acceptable and what questions can be asked, we risk our commitment to the pursuit of new knowledge.

\section{What needs to be done?}

One path forward is for college and university leadership to reaffirm their institutions' commitment to free speech and academic freedom as fundamental values of any university and of our democracy. It has been taken as given, and in many cases, included in university governance documents or by-laws. But, it has not been a major topic of discussion for some period of time. Greater articulation of the institution's values for all

\footnotetext{
6 John Villasenor, "Views Among College Students Regarding the First Amendment: Results from a New Survey," Brookings Institution, last updated September 18, 2017, https://www.brookings.edu/blog/fixgov/2017/09/18/views-among-college-studentsregarding-the-first-amendment-results-from-a-new-survey/.
} 
to hear, including faculty and students as well as alumni, would be useful. Such conversations around institutional values are already happening in some contexts, spurred by the campus unrest described above.

The most complicated situations are when the commitment to free speech comes into conflict with other important institutional commitments, such as policies against harassment and discrimination. The latter policies recognize that certain forms of speech can cause real harm, especially to historically marginalized groups. Greater clarity around these issues would be helpful to institutions as they respond to incidents on campus. Having clearly articulated policies and procedures for determining what actions violate policies are key. While each incident will be unique in some way, if colleges and universities are unclear on their policies and processes, it is difficult to avoid being perceived as responding ad hoc to each event as a crisis.

This is exceedingly complicated terrain. While commitments to free speech and academic freedom should not be used to defend harassment and discrimination, they in turn cannot be used to stifle free speech and academic freedom, or these principles are at risk. Institutions need to confront these issues as forthrightly as possible and articulate their communities' standards for their campuses. ${ }^{7}$

Since free speech and academic freedom are key values and core to any college or university's educational mission, one goal of education should be to instill these values in our graduates and the next generation. More important than holding community members accountable for violating these values is convincing them of their worth, not only to the academic endeavor, but to our society. This means convincing those who feel that free speech has been used as a means of oppression that, in fact, it is a key to protection against such oppression. Education is often talked about as a public good, contributing to good citizens. This is perhaps one of the most important ways in which it can do so.

Allowing a heckler's veto, or even concerns of violence, to disrupt permitted speakers puts the commitment to free speech at risk. If free speech is suppressed through violence, then of course free speech is at risk, since promoting violence is an easy strategy for preventing any speakers with whom one group disagrees. Institutions have an obligation to not allow this to happen. A more robust process for inviting and approving campus speakers that is applied consistently across speakers representing all perspectives, and having clear policies about how the costs of security are allocated among the institution, the inviting group, and the invited speaker, may help to mitigate

7 "Report of the Committee on Freedom of Expression at Yale," (New Haven, CT: Yale University, December 1974). 
the risk of this kind of disruption. This would avoid some of the problems of speakers invited at the last minute, or for whom there is not appropriate space or security available on short notice. This also allows schools to plan for any anticipated controversy around speakers.

\section{Allowing a heckler's veto, or even concerns of violence, to disrupt permitted speakers puts the commitment to free speech at risk.}

Perhaps as important as including speakers with different points of view, the classroom needs to be a space where differing points of view are explored and valued. Faculty need to feel protected by their institutions against attacks on the part of students, whether in the classroom or in public spaces, such as teach-ins or debates. In the same way that students are objecting to hearing from speakers with whom they disagree, they are challenging professors in the same way. If that takes the form of silencing or intimidating professors into self-censorship, then our academic mission could be at serious risk. There needs to be a way to protect faculty, while also protecting students from harassment and discrimination, but not from challenging ideas. If we are asking faculty to participate in these discussions and debates, institutions need to protect them when they speak freely, as they must do with other members of their communities. Faculty are key: if they withdraw, because it is safer to do so, teaching and learning will suffer. On the other hand, some faculty in some fields see their scholarship and activism as inseparable. This creates additional challenges for institutions, in that their classrooms may not be hospitable places for students with points of view that differ from these faculty. The challenge is to enable faculty to be demanding in their classrooms, while protecting students from harassment and discrimination. The ways in which institutions articulate and enforce their policies are incredibly important to accomplishing this outcome. 


\section{Next steps}

Many of us believe in the importance of the First Amendment to American democracy and to academic freedom to encourage the pursuit of knowledge. In our role as educators and leaders of institutions of higher education, one of our goals should be to pass along our commitment to these principles to students. To fulfill their mission of pursuing knowledge and educating engaged citizens, colleges and universities must be sites where debate and inquiry thrive. That in turn requires respecting the rights of all stakeholders-students, faculty, alumni, and administrators, including presidents-to express their views without fear of being silenced.

Based on the discussion above, we see four important next steps for institutional leaders and the broader higher education community:

1. Develop model processes for inviting and making campus facilities available to speakers, and model policies for addressing disruption of scheduled speakers. ${ }^{8}$

2. Develop model principles that protect free speech and academic freedom and encourage a culture on campus that recognizes the importance of anti-discrimination and anti-harassment policies, and develop strategies for addressing the most likely scenarios in which these conflicts arise.

3. Engage campus communities in robust discussion of institutional values regarding free speech and open inquiry, recruiting faculty to develop curricular components reflecting the history and philosophy of those principles. Use these opportunities to model intellectual discourse regarding opposing views.

4. Develop strategies for ensuring there is a reasonable level of funds to cover the costsincluding security costs-of protecting controversial speech. ${ }^{9}$

As the members of our college communities become more diverse in their backgrounds, as the flood of information expands, as our politics become more polarized, and as social media democratizes the ability to amplify speech and also makes it possible to limit what we hear and see, there is a great risk that college campuses and classrooms shift from

\footnotetext{
8 We are not suggesting that particular speakers need approval, but that who can invite speakers should be clear. Is it only approved student groups, or can any individual student invite a speaker? Can alumni invite speakers? Once policies are agreed to, they need to be applied neutrally without regard to the positions or views of the speakers.

${ }^{9}$ An unresolved issue is exactly how much an institution should be expected to spend on security for any individual speaker. Given financial constraints at institutions, a completely open ended obligation would be challenging. Whatever is decided, it needs to be implemented in a neutral fashion. Using security costs as a reason to prevent speakers from coming to campus could create significant challenges to the commitment to free speech.
}

FREE SPEECH, STUDENT ACTIVISM, AND SOCIAL MEDIA: REFLECTIONS FROM THE BOWEN COLLOQUIUM ON HIGHER EDUCATION LEADERSHIP 


\section{ITHAKA S+R}

fora for open discourse to a set of insular enclaves of the like-minded. It is precisely at this moment that institutions committed to the pursuit of knowledge should reinforce their policies and practices to bolster free speech and academic freedom. 